\title{
Air-Pollutant-Philic Plants for Air Remediation
}

\author{
Misa Takahashi, Hiromichi Morikawa
}

Department of Mathematical and Life Sciences, Graduate School of Science, Hiroshima University, Higashi-Hiroshima, Japan. Email: mtakahas@sci.hiroshima-u.ac.jp

Received July $23^{\text {rd }}, 2012$; revised August $24^{\text {th }}, 2012$; accepted September $19^{\text {th }}, 2012$

\begin{abstract}
In this communication, we review our work over two decades on air-pollutant-philic plants that can grow with air pollutants as the sole nutrient source. We believe that such plants are instrumental in mitigating air pollution. Our target air pollutant has been atmospheric nitrogen dioxide $\left(\mathrm{NO}_{2}\right)$, and our work on this subject has consisted of three parts: Variation in plants' abilities to mitigate air pollutants among naturally occurring plants, genetic improvement of plants' abilities to mitigate air pollutants, and the plant vitalization effect of $\mathrm{NO}_{2}$. So far, an estimation of the half-life of nitrogen derived from $\mathrm{NO}_{2}$ uptake in plants belonging to the 217 taxa studied to date has shown no plants to be naturally occurring air-pollutant-philic. However, we found that an enormous difference exists in plants' ability to uptake and assimilate atmospheric $\mathrm{NO}_{2}$. Future studies on the causes of this process may provide an important clue to aid the genetic production of plants that are effectively air-pollutant-philic. Both genetic engineering of the genes involved in the primary nitrate metabolism and genetic modification by ion-beam irradiation failed to make plants air-pollutant-philic, but mutants obtained in these studies will prove useful in revealing those genes critical in doing so. During our study on air-pollutant-philic plants, we unexpectedly discovered that prolonged exposure of plants to a sufficient level of $\mathrm{NO}_{2}$ activates the uptake and metabolism of nutrients that fuel plant growth and development. We named this phenomenon "the plant vitalization effect of $\mathrm{NO}_{2}$ " (PVEON). Investigations into the mechanisms and genes involved in PVEON will provide an important clue to making plants air-pollutant-philic in the future.
\end{abstract}

Keywords: Air-Pollutant-Philic Plants; Air Remediation; Genetic Modification; Nitrogen Dioxide $\left(\mathrm{NO}_{2}\right)$; Plant Vitalization Effect of $\mathrm{NO}_{2}$

\section{Introduction}

Over two decades ago, we started research investigating air-pollutant-philic plants that can grow with air pollutants as the sole nutrient source $[1,2]$. We thought (and still think) that such plants are critical for mitigation of air pollution. Our idea is a critical response to the need to cope with harsh air pollution worldwide and is a viable possibility due to plants' natural ability as a sink of various air pollutants. Although we still have much ground to cover and are not as far along as we had had hoped, we have made some progress in the research of air-pollutantphilic plants.

We have primarily focused on atmospheric nitrogen dioxide $\left(\mathrm{NO}_{2}\right)$ as a target pollutant. The weighted average of $\mathrm{NO}_{2}$ concentration in cities from over 141 countries is reported to be $50.6 \mu \mathrm{g} / \mathrm{m}^{3}(\approx 27 \mathrm{ppb})$ [3]. The current WHO air quality guideline value (annual mean) for $\mathrm{NO}_{2}$ is $40 \mu \mathrm{g} / \mathrm{m}^{3}(\approx 21 \mathrm{ppb})$ [4].

The air in polluted urban areas of Japan contains about $0.05 \mathrm{ppm}$ of $\mathrm{NO}_{2}$, a similar or even higher amount of nitrogen oxide (NO), and $0.1 \mathrm{ppm}$ of non-methane hydrocarbons (NMHCs) [5]. Methane and other volatile organic hydrocarbons, including NMHCs, photochemically produce hydroxyl radicals (highly reactive molecules containing a single unpaired electron), which react with nitrogen oxides $\left(\mathrm{NO}_{\mathrm{x}}\right)$ to produce photooxidative ozone. $\mathrm{NO}_{2}$ and oxidants remain in the lower atmosphere (troposphere) and are very toxic gases for animals, including humans, as well as for plants [6]. Gaseous pollutants such as $\mathrm{NO}_{\mathrm{x}}$, once emitted, disperse into the atmosphere rapidly. Centralized treatment of these scattered pollutants is energy (equivalent to the entropy) intensive and costly. In contrast, plants are driven by solar energy, are self-reproducing, and can concentrate and detoxify pollutants. Therefore, plants should prove to be very useful in helping to clean up dispersed, ambient pollutants. In fact, we know that plants do uptake $\mathrm{NO}_{2}$ [7-11] and incorporate its nitrogen into organic nitrogenous compounds [12-15].

\section{Variation in Plants' Abilities to Mitigate Air Pollutants among Naturally Occurring Plants}

Learning to what extent naturally occurring plants are (or 
are not) air-pollutant-philic is important. We therefore investigated the uptake and assimilation of $\mathrm{NO}_{2}$ in 217 taxa of naturally occurring plants that included 107 woody plants, 60 cultivated herbaceous plants, and 50 wild herbaceous plants collected from roadsides.

Plants were fumigated in a fumigation chamber at $22^{\circ} \mathrm{C}$ $\pm 0.3^{\circ} \mathrm{C}, 70 \% \pm 4 \%$ relative humidity, and an atmospheric level of $0.03 \%$ to $0.04 \% \mathrm{CO}_{2}$ for $8 \mathrm{~h}$ during daytime (09:00 - 17:00) under fluorescent lights $(70 \mu \mathrm{mol}$ photons $\left.\mathrm{m}^{-2} \cdot \mathrm{s}^{-1}\right)$ with $4 \pm 0.4 \mathrm{ppm}{ }^{15} \mathrm{NO}_{2}\left(51.6\right.$ atom $\left.\%{ }^{15} \mathrm{~N}\right)$. Leaves were then cut from fumigated plants, washed with tap water and then with distilled water, and lyophilized. Lyophilized leaves were then analyzed for the ${ }^{14} \mathrm{~N}$ plus ${ }^{15} \mathrm{~N}$ content and the percentage of ${ }^{15} \mathrm{~N}$ in the samples was determined using an EA-MS analyzer in which an elemental analyzer (EA/NA; Fisons Instruments, Milano, Italy) interfaced with a mass spectrometer (Delta $C$; Thermo Finnigan, Bremen, Germany), as described previously [16]. From these two values, total $\left({ }^{14} \mathrm{~N}\right.$ plus $\left.{ }^{15} \mathrm{~N}\right)$ nitrogen derived from $\mathrm{NO}_{2}$ in the leaves of fumigated plants (mg N/g dry weight) was determined (designated $\mathrm{TNNO}_{2}$ ). Parts of the lyophilized leaves were subjected to Kjeldahl digestion [17,18], and the reduced or Kjeldahl nitrogen fraction was obtained. The ${ }^{14} \mathrm{~N}$ plus ${ }^{15} \mathrm{~N}$ content and the percentage of ${ }^{15} \mathrm{~N}$ in the Kjeldahl fraction were then analyzed. From these values, reduced nitrogen derived from $\mathrm{NO}_{2}$ in the leaves of fumigated plants (mg N/g dry weight) was determined (designated $\mathrm{RNNO}_{2}$ ). $\mathrm{TNNO}_{2}$ (mg N/g dry wt), $\mathrm{RNNO}_{2}$ (mg N/g dry weight), and the ratio of $\mathrm{RNNO}_{2} / \mathrm{RN}$ (\%) respectively give a measure of the ability of plants to act as a sink for $\mathrm{NO}_{2}$, that of the ability of plants to metabolize (assimilate) $\mathrm{NO}_{2}$, and of the contribution of $\mathrm{NO}_{2}$ as a nitrogen source.

Details of the data on 217 taxa have been published
$[16,19]$, and here we briefly discuss some points in relation to the air-pollutant-philic plants. Among the 217 taxa, the $\mathrm{RNNO}_{2}$ differed by a factor of 657 between the highest (Eucalyptus viminalis, 6.57) and lowest (Tillandsia ionantha and Tillandsia caput-medusae, 0.01). These two species belong to the Myrtaceae and Bromeliaceae family, respectively. The Myrtaceae seems to include plants with a high ability to assimilate $\mathrm{NO}_{2}$ (see below), and plants of the Bromeliaceae have less of an ability to assimilate $\mathrm{NO}_{2}$. The other two species of the Bromeliaceae also showed low values for $\mathrm{RNNO}_{2}: 0.02$ and 0.12 in Tillandsia usneoides and Tillandsia geminiflora, respectively.

The $\mathrm{RNNO}_{2} / \mathrm{RN}$ differed about 85 -fold between the highest (Magnolia kobus, 12.7\%) and lowest (Codiaeum variegatum, $0.15 \%$ ). These two species belong to the Magnoliaceae and Euphorbiaceae family, respectively. The 217 taxa examined included no other species of the Magnoliaceae. One species of the 217 taxa, belonging to the Euphorbiaceae, Sapium sebiferum, showed a particularly high value of $\mathrm{RNNO}_{2} / \mathrm{RN}$ (10.1) [16].

Among the 217 taxa, six woody species, one cultivated herbaceous species, and two wild herbaceous species collected from roadsides were found to have $\mathrm{RNNO}_{2}$ greater than 4 and $\mathrm{RNNO}_{2} / \mathrm{RN}$ values greater than or close to 9 as shown in Table 1. These nine species may have more potential to be air-pollutant-philic specimens than those examined in the 217 taxa examined to date.

Since the fumigation in our study described above lasted for $8 \mathrm{~h}, \mathrm{RNNO}_{2} / \mathrm{RN}$ values reflect the turnover rate of reduced nitrogen in plants. Turnover of reduced nitrogen is considered to be first order as in the case of proteins [20]. A simple exponential curve was fitted to the $\mathrm{RNNO}_{2} / \mathrm{RN}$ data to generate a first-order rated constant: $k$. The half-life of the reduced nitrogen was calculated as

Table 1. Nine species with high values of reduced nitrogen derived from $\mathrm{NO}_{2}\left(\mathrm{RNNO}_{2}\right)$ and the corresponding percentage of $\mathrm{RNNO}_{2}$ in the total reduced nitrogen $\left(\mathrm{RNNO}_{2} / \mathrm{RN}\right)$.

\begin{tabular}{|c|c|c|c|}
\hline Species & $\mathrm{RNNO}_{2}(\mathrm{mgN} / \mathrm{g}$ dry wt) & $\mathrm{RNNO}_{2} / \mathrm{RN}(\%)$ & Family \\
\hline \multicolumn{4}{|l|}{ Woody species } \\
\hline Eucalyptus viminalis & 6.57 & 12.5 & Myrtaceae \\
\hline Populus nigra & 5.14 & 10.7 & Salicaceae \\
\hline Magnolia kobus & 4.92 & 12.7 & Magnoliaceae \\
\hline Eucalyptus grandis & 4.57 & 8.5 & Myrtaceae \\
\hline Eucalyptus globulus & 4.08 & 9.4 & Myrtaceae \\
\hline \multicolumn{4}{|l|}{ Cultivated herbaceous species } \\
\hline Nicotiana tabacum & 5.72 & 11.4 & Solanaceae \\
\hline \multicolumn{4}{|l|}{ Wild herbaceous species } \\
\hline Crassocephalum crepidioides & 5.07 & 9.2 & Compositae \\
\hline
\end{tabular}


$t_{1 / 2}=\ln (2) / k$. In the aforementioned nine species, the half-life of reduced nitrogen for $M$. kobus with the highest $\mathrm{RNNO}_{2} / \mathrm{RN}$ value (see Table 1) was calculated to be approximately $40 \mathrm{~h}$. This value is comparable to the half-life of Cullin-associated and neddylation-dissociated 1 (CAND1; $30 \mathrm{~h}$ ) and that of Transport inhibitor response 1 (TIR1; $10 \mathrm{~h}$ ) proteins [20]. However, assuming a linear dependence of the turnover rate on the concentration of $\mathrm{NO}_{2}$, the half-life of the reduced nitrogen at 0.04 ppm is estimated to be $4000 \mathrm{~h}$. More recently, we found that $14 \%$ of $\mathrm{TNNO}_{2}$ was derived from $\mathrm{NO}_{2}$ in cucumber (Cucumis sativus) plants grown under natural lighting in the presence of $100 \pm 50 \mathrm{ppb} \mathrm{NO}_{2}$ for 5 weeks [21]. Using these values and the assumptions described above, the half-life of total nitrogen in cucumber was estimated to be $1000 \mathrm{~h}$. Obviously, these calculations of half-lives of nitrogen-derived from $\mathrm{NO}_{2}$ in the selected species indicates that no naturally occurring plants studied to date are air-pollutant-philic. However, the existence of great differences in both $\mathrm{RNNO}_{2}$ and $\mathrm{RNNO}_{2} / \mathrm{RN}$ is encouraging for the fabrication of air-pollutant-philic plants. Investigations on the causes for the differences in these parameters between species or how the metabolism of $\mathrm{NO}_{2}$ differs between species may provide an important clue to improve plants' abilities to assimilate $\mathrm{NO}_{2}$ and hence to make plants air-pollutant-philic agents.

In the 217 taxa examined, the $\mathrm{RNNO}_{2}$ value varied among the individuals of a species [16]. This variation was more pronounced in the wild herbaceous and woody plants than in the cultivated herbaceous plants. Among wild herbaceous plants (19 individuals), the variation was 26.2-fold in Solidago altissima, 21.4-fold in Rumex acetosella, and 17.6-fold in Crassocephalum crepidioides. In woody plants, the corresponding value was 11.9-fold in M. kobus, 10.6-fold in Euonymus japonicus, and 6.7-fold in Prunus cerasoides [16]. Understanding differences among individuals of the same species in their abilities to assimilate $\mathrm{NO}_{2}$ is also important in terms of genetically constructing air-pollutant-philic plants.

We attempted selection of "mutant" lines of Rhododendron mucronatum, which is widely used as roadside trees and can be propagated by cuttings [22]. R. mucronatum was ranked $105^{\text {th }}$ among the 217 taxa in $\mathrm{RNNO}_{2}$. In 1996, 1452 different cutting lines of $R$. mucronatum (referred to as the "96-plants") were fumigated with 4 ppm ${ }^{15} \mathrm{NO}_{2}$ for $8 \mathrm{~h}$, and $\mathrm{TNNO}_{2}$ in the leaves was determined. A 56-fold difference was observed between the individuals with the highest and lowest capacities. We propagated approximately 100 lines (designated the " 97 plants") each from the high-, middle-, and low-capacity groups, and assayed them for $\mathrm{TNNO}_{2}$ in the following year. The maximum variation in $\mathrm{TNNO}_{2}$ was 5.6 times.
In 1998, 227 lines propagated from the 96-plants and 95 lines from the 97-plants (the "98-plants") were assayed for $\mathrm{TNNO}_{2}$. The variations in $\mathrm{TNNO}_{2}$ in the 97- and 98plants were maximally 4.9 and 5.2 times, respectively. The reason(s) for the disappearance of the initial large variation in $\mathrm{TNNO}_{2}$ remains unclear.

\section{Genetic Improvement of Plants' Abilities to Mitigate Air Pollutants}

Foliar uptake of $\mathrm{NO}_{2}$ is believed to occur via stomatal and nonstomatal pathways as a gas or as nitrite or nitrate [11]. However, the precise mechanisms remain unclear. Most $\mathrm{NO}_{2}$ molecules taken up into plants are converted, either chemically or enzymatically, to nitrate and nitrite, assimilated to ammonia, and incorporated into amino acids and other organic nitrogenous compounds through the primary nitrate assimilation pathway [12-15]. In the primary nitrate pathway, nitrate is converted to nitrite by a two-electron reduction catalyzed by the nitrate reducetase (NR), the first enzyme. The second enzyme, nitrite reductase $(\mathrm{NiR})$, catalyzes a six-electron reduction to convert nitrite to ammonia. Ammonia thus formed is incorporated into glutamic acid to form glutamine by the glutamine synthetase (GS), the third enzyme. Therefore, engineering of these genes should be instrumental to improve metabolism of $\mathrm{NO}_{2}$ and help make plants air-pollutant-philic.

To date we have produced transgenic plants of Arabidopsis thaliana (Cruciferae), a model species that overexpresses any one of the three genes of the primary nitrate reduction pathway [17]. We have also produced transgenic plants of Rhaphiolepis umbellata (Rosaceae) that overexpress the NiR gene [23]. R. umbellata is a very popular roadside shrub in Japan. Finally, we produced mutants of Ficus pumila (Moraceae) using an ion-beam-irradiation technique [24], an emerging method to produce various mutants [25]. F. pumila is an evergreen climber that is sometimes used to cover the walls of houses and buildings. Data on the uptake and assimilation of $\mathrm{NO}_{2}$ by these three genetically modified plants are shown in Table 2.

The uptake of $\mathrm{NO}_{2}$ in transgenic R. umbellata and ion-beam-irradiated $F$. pumila was 1.8 to 1.9 times greater compared with their respective control plants (Table 2). Although these increases in the uptake of $\mathrm{NO}_{2}$ may not be enough to make these plants air-pollutantphilic, note that engineering of the NiR gene and ionbeam irradiation in F. pumila did improve the plants' abilities to uptake $\mathrm{NO}_{2}$. Future studies investigating what causes the increase in uptake of $\mathrm{NO}_{2}$ in these modified plants may provide some information that is helpful in making plants air-pollutant-philic.

The assimilation of $\mathrm{NO}_{2}$ in transgenic $A$. thaliana and R. umbellata, and ion-beam-irradiated F. pumila, was 1.6 - 
Table 2. Total nitrogen derived from $\mathrm{NO}_{2}\left(\mathrm{TNNO}_{2}\right)$ and reduced nitrogen derived from $\mathrm{NO}_{2}\left(\mathrm{RNNO}_{2}\right)$ in transgenic Arabidopsis thaliana and Rhaphiolepis umbellata plants, and plants regenerated from ion-beam-irradiated explants of Ficus pumila.

\begin{tabular}{|c|c|c|c|c|c|c|c|c|c|c|}
\hline & \multicolumn{5}{|c|}{$\mathrm{NO}_{2}$ uptake $\left(\mathrm{TNNO}_{2} \mu \mathrm{gN} / \mathrm{gDW}\right)$} & \multicolumn{5}{|c|}{$\mathrm{NO}_{2}$ assimilation $\left(\mathrm{RNNO}_{2} \mu \mathrm{gN} / \mathrm{gDW}\right)$} \\
\hline & $\begin{array}{c}\text { Transgenic or } \\
\text { irradiated }\end{array}$ & $n$ & Wild type & $n$ & Fold & $\begin{array}{c}\text { Transgenic or } \\
\text { irradiated }\end{array}$ & $n$ & Wild type & $n$ & Fold \\
\hline Arabidopsis thaliana & - & - & - & - & - & $1650 \pm 140^{* *}$ & 3 & $1018 \pm 80$ & 3 & 1.6 \\
\hline Rhaphiolepis umbellate & 333 & 1 & $174.2 \pm 4.0$ & 3 & 1.9 & 282 & 1 & 170.1 & 1 & 1.7 \\
\hline Ficus pumila & $635 \pm 160^{*}$ & 9 & $457 \pm 108$ & 10 & 1.8 & $519 \pm 83^{* *}$ & 6 & $293 \pm 72$ & 3 & 1.8 \\
\hline
\end{tabular}

A. thaliana, R. umbellate, and F. pumila were fumigated with $4 \mathrm{ppm} \mathrm{NO}_{2}$ for $8 \mathrm{~h}$ under artificial light [17] with $0.2 \mathrm{ppm}_{* *} \mathrm{NO}_{2}$ for 1 week under natural light [23], or with $1 \mathrm{ppm}{ }^{15} \mathrm{~N}$-labeled $\mathrm{NO}_{2}$ for $8 \mathrm{~h}$ under artificial light [24], respectively. Data represent the mean $\pm \mathrm{SD}$. ${ }^{*} \mathrm{P}<0.05$, ${ }^{* *} \mathrm{P}<0.01$.

1.8 times greater compared with their respective control plants (Table 2). Thus, gene engineering of the NiR gene and ion-beam irradiation improved plants' abilities to assimilate $\mathrm{NO}_{2}$. This finding was in contrast to the effects of overexpressing NR and GS (see below). In transgenic A. thaliana, a 1.5-time increase in NiR enzyme activity was observed as compared to the control [17]. The increase in the ability of assimilating $\mathrm{NO}_{2}$ in transgenic A. thaliana can therefore be attributed to the increase in NiR activity. However, no such increase in NiR activity was observed in ion-beam-irradiated F. pumila [24]. This implies that genetic change(s) other than manipulation of the NiR gene may be capable of improving the assimilation of $\mathrm{NO}_{2}$. Future studies on the molecular causes of improved $\mathrm{NO}_{2}$ assimilation in ion-beam-irradiated $F$. pumila may provide a clue to help create airpollutant-philic plants.

In the case of the overexpression of NR and GS in A. thaliana, no significant increases in the uptake or assimilation of $\mathrm{NO}_{2}$ was observed despite respective enzyme activities having been increased by 1.8 - and 1.5-fold compared to the controls [17]. Taken together with the above results on NiR overexpresssion, NiR, but not NR or GS, is a controlling enzyme of $\mathrm{NO}_{2}$ assimilation in plants. This conclusion was supported by the determination of the flux control coefficient, a measure of the effect of change in a single enzyme activity on flux $[26,27]$ as described previously [17].

\section{Plant Vitalization Effect of $\mathrm{NO}_{2}$}

During our study on air-pollutant-philic plants, we unexpectedly discovered that prolonged exposure of plants to a sufficient level of $\mathrm{NO}_{2}$ activates the uptake and metabolism of nutrients that fuel plant growth and development [28]. We named this phenomenon the plant vitalization effect of $\mathrm{NO}_{2}$ (PVEON).

In the literature, atmospheric $\mathrm{NO}_{2}$ has been regarded as being either detrimental $[15,29]$ or beneficial $[30,31]$ to plants depending on the plant's nitrogen nutrient conditions. Recent reports that $\mathrm{NO}_{2}$ stimulates or fails to stimulate the growth of a particular plant $[32,33]$ suggest that this debate is still active. We speculate that a cause for this discrepancy may be that the response of plant growth to $\mathrm{NO}_{2}$ is highly dependent on the target species, and thus both the concentration of $\mathrm{NO}_{2}$ and duration of exposure to $\mathrm{NO}_{2}$ need to be optimized for each plant species to observe the PVEON.

The PVEON was first found in Nicotiana plumbaginifolia [28], and then in other species such as cucumber, kenaf, lettuce, pumpkin, and tomato (Table 3) $[21,28,34,35]$. Shoot biomass in $\mathrm{NO}_{2}$-exposed plants $\left(+\mathrm{NO}_{2}\right)$ was 1.4- to 2.4 -fold greater than that in non-exposed $\left(-\mathrm{NO}_{2}\right)$ plants. A. thaliana showed PVEON and its increase in shoot biomass in response to this effect differed between the accessions Columbia and C24 (1.6and 2.3-fold, respectively) compared to no-exposure plants when plants were exposed to $50 \mathrm{ppb} \mathrm{NO}_{2}$ for 3 weeks [35]. The optimal $\mathrm{NO}_{2}$ concentration for the PVEON varied from 50 to $200 \mathrm{ppb}$ depending on the species. The duration of exposure to $\mathrm{NO}_{2}$ was changed from 3 to 12 weeks as a function of target species (Table 3). The increase in shoot biomass in response to PVEON was always accompanied by an increase in total leaf area in all plant species studied to date. In Nicotiana plumbaginifolia, the contents per shoot of $\mathrm{C}, \mathrm{N}, \mathrm{S}, \mathrm{P}, \mathrm{K}, \mathrm{Ca}, \mathrm{Mg}$, free amino acids and crude proteins were almost doubled in $+\mathrm{NO}_{2}$ plants compared with $-\mathrm{NO}_{2}$ plants [28].

In tomato (cv. Micro-Tom), the PVEON significantly increases the yield of fruits (Table 3). This increase in fruit yield was accompanied by acceleration of flowering time by 3.2 days and an increase in flower number per plant of up to $60 \%$. Not surprisingly, the average weight of a tomato fruit was not significantly different between $+\mathrm{NO}_{2}$ plants and $-\mathrm{NO}_{2}$ plants, but the number of fruits on a plant was distinctly increased in the former [35]. Thus, the PVEON increases fruit yield via stimulation of flowering in tomato. This is in sharp contrast to Spierings' [36] report that exposure of Moneymaker tomato plants to $\mathrm{NO}_{2}$ at $250 \mathrm{ppb}$ during the entire growth period of about 4 months caused a $22 \%$ decrease in fruit yield. In addition, Spierings [36] found that $\mathrm{NO}_{2}$ was detrimental to the vegetative growth of Moneymaker; fumigation with $\mathrm{NO}_{2}$ increased the height of very young plants, but resulted in smaller leaves and shorter petioles, and 
Table 3. Effects of exposure to $\mathrm{NO}_{2}$ on the yield of shoot biomass or fruit.

\begin{tabular}{|c|c|c|c|c|c|c|}
\hline Species & $\mathrm{NO}_{2}(\mathrm{ppb})$ & Exposure duration (weeks) & Shoot biomass (mg/plant) & Fruit yield (g/plant) & $n$ & Fold \\
\hline \multicolumn{7}{|c|}{ Cucumis sativus (cucumber) $^{1}$} \\
\hline$-\mathrm{NO}_{2}$ & $<5$ & 5 & $370 \pm 90$ & - & 3 & \\
\hline$+\mathrm{NO}_{2}$ & $100 \pm 50$ & 5 & $620 \pm 110^{*}$ & - & 3 & $1.7 \pm 0.3$ \\
\hline \multicolumn{7}{|c|}{ Cucurbita moschata (pumpkin) ${ }^{2}$} \\
\hline$-\mathrm{NO}_{2}$ & $<5$ & 5 & $5300 \pm 100$ & - & 3 & \\
\hline$+\mathrm{NO}_{2}$ & $200 \pm 50$ & 5 & $8300 \pm 1000^{*}$ & - & 3 & $1.6 \pm 0.2$ \\
\hline \multicolumn{7}{|c|}{ Helianthus annuus (sunflower) ${ }^{3}$} \\
\hline$-\mathrm{NO}_{2}$ & $<5$ & 6 & $1760 \pm 810$ & - & 3 & \\
\hline$+\mathrm{NO}_{2}$ & $200 \pm 50$ & 6 & $3550 \pm 30^{*}$ & - & 3 & $2.0 \pm 0.02$ \\
\hline \multicolumn{7}{|c|}{ Hibiscus cannabinus (kenaf) ${ }^{4}$} \\
\hline$-\mathrm{NO}_{2}$ & $<5$ & 3 & $586 \pm 284$ & - & 5 & \\
\hline$+\mathrm{NO}_{2}$ & $100 \pm 50$ & 3 & $793 \pm 119$ & - & 5 & $1.4 \pm 0.2$ \\
\hline \multicolumn{7}{|c|}{ Lactuca sativa (lettuce) $)^{5}$} \\
\hline$-\mathrm{NO}_{2}$ & $<5$ & 6 & $140 \pm 70$ & - & 3 & \\
\hline$+\mathrm{NO}_{2}$ & $50 \pm 10$ & 6 & $340 \pm 90^{*}$ & - & 3 & $2.4 \pm 0.7$ \\
\hline \multicolumn{7}{|c|}{ Nicotiana plumbaginifolia ${ }^{6}$} \\
\hline$-\mathrm{NO}_{2}$ & $<5$ & 10 & $1044 \pm 87$ & - & 6 & \\
\hline$+\mathrm{NO}_{2}$ & $150 \pm 50$ & 10 & $1767 \pm 119^{* * *}$ & - & 6 & $1.7 \pm 0.1$ \\
\hline \multicolumn{7}{|c|}{ Solanum lycopersicum (tomato) ${ }^{7}$} \\
\hline$-\mathrm{NO}_{2}$ & $<5$ & 12 & - & $50.9 \pm 8.7$ & 10 & \\
\hline$+\mathrm{NO}_{2}$ & $50 \pm 10$ & 12 & - & $70.0 \pm 14.6^{* *}$ & 10 & $1.4 \pm 0.2$ \\
\hline
\end{tabular}

1-3,5[21]; ${ }^{4}[35] ;{ }^{6}[28] ;{ }^{7}[36] .{ }^{* * *} \mathrm{P}<0.001,{ }^{* *} \mathrm{P}<0.01,{ }^{*} \mathrm{P}<0.05$.

caused a loss of leaves. These findings are also contrary to our results for Micro-Tom, where no detrimental effect of $\mathrm{NO}_{2}$ on vegetative growth was observed, and the biomass yield of Micro-Tom plants grown with or without $50 \mathrm{ppb} \mathrm{NO}_{2}$ was not significantly different. The reason for these discrepancies remains unclear.

Based on the mass spectrometric analysis on the ${ }^{15} \mathrm{~N} /{ }^{14} \mathrm{~N}$ ratio, it was found that $\mathrm{NO}_{2}$-derived $\mathrm{N}\left(\mathrm{NO}_{2}-\mathrm{N}\right)$ comprised less than $3 \%-14 \%$ of the total plant nitrogen $[21,28,34]$, indicating that PVEON is due to the effect of $\mathrm{NO}_{2}$ as a signal rather than as a nitrogen source. This speculation is in line with the common understanding that $\mathrm{NO}_{2}$ is a reactive nitrogen species acting as a cellular signal in both plants and animals.

The molecular mechanisms of PVEON and the genes involved in PVEON are currently being investigated using Arabidopsis plants. Histological analyses examining the causes of an approximately two times increase in leaf size in Arabidopsis plants indicates that an increase in cell size rather than cell number is the most probable cause. Based on transcriptome analysis, we found that destruction of a gene (Vita 1) causes loss of PVEON. Thus, this gene is a PVEON-responsive gene in Arabidopsis plants. These genes will prove useful in helping to make plants air-pollutant-philic in future studies.

\section{Acknowledgements}

This work was supported in part by a Grant-in-Aid for Scientific Research (nos.18770037 and 21580403) from the Japan Society for the Promotion of Science and by the Research for Promoting Technological Seeds Program of the Japan Science and Technology Agency.

\section{REFERENCES}

[1] H. Morikawa, A. Higaki, M. Nohno, M. Kamada, M. Nakata, G. Toyohara, K. Fujita and K. Irifune, "Air-Pollutant-Philic Plants from Nature," In: N. Murata, Ed., Research in Photosynthesis, Vol. IV, Kluwer Academic Publishers, Dordrecht, 1992, pp. 79-82.

[2] M. Kamada, A. Higaki, Y. Jin, M. Ayabe, M. Seki, T. Sawasaki, S. Ida, G. Toyohara, K. Irifune and H. Morikawa, “Transgenic 'Air-Pollutant-Philic Plants' Produced by Particle Bombardment," In: N. Murata, Ed., Research in Photosynthesis, Vol. IV, Kluwer Academic Publishers, Dordrecht, 1992, pp. 83-86.

[3] NationMaster, "Urban $\mathrm{NO}_{2}$ Concentration (Most Recent) by Country,"

http://www.nationmaster.com/graph/env_urb_no2_con-en 
vironment-urban-no2-concentratio

[4] WHO, “Air Quality and Health,” 2011. http://www.who.int/mediacentre/factsheets/fs313/en/inde x.html

[5] Ministry of the Environment of Government of Japan, "White Paper," http://www.env.go.jp/en

[6] A. R. Wellburn, "Air Pollution and Climate Change: The Biological Impact," Longman Scientific \& Technical, Harlow, 1994.

[7] A. J. Zeevaart, "Some Effects of Fumigating Plants for Short Periods with $\mathrm{NO}_{2}$," Environmental Pollution, Vol. 11, No. 2, 1976, pp. 97-108. doi:10.1016/0013-9327(76)90022-7

[8] Y.-N. Lee and S. E. Schwartz, "Reaction Kinetics of Nitrogen Dioxide with Liquid Water at Low Partial Pressure," Journal of Physical Chemistry, Vol. 85, No. 7, 1981, pp. 840-848. doi:10.1021/j150607a022

[9] A. Rowland, A. J. S. Murray and A. R. Wellburn, "Oxides of Nitrogen and Their Impact upon Vegetation," Reviews on Environmental Health, Vol. 5, No. 4, 1985, pp. 295-342.

[10] P. Ramge, F.-W. Badeck, M. Plöchl and G. H. Kohlmaier, "Apoplastic Antioxidants as Decisive Elimination Factors within the Uptake Process of Nitrogen Dioxide into Leaf Tissues," New Phytologist, Vol. 125, No. 4, 1993, pp. 771785. doi:10.1111/j.1469-8137.1993.tb03927.x

[11] W. Larcher, "Physiological Plant Ecology," Springer-Verlag, Berlin, 1995. doi:10.1007/978-3-642-87851-0

[12] S. V. Durmishidze and N. N. Nutsubidze, "Absorption and Conversion of Nitrogen Dioxide by Higher Plants," Doklady Biochemistry and Biophysics, Vol. 227, 1976, pp. 104107.

[13] H. H. Rogers, J. C. Campbell and R. J. Volk, "Nitrogen15 Dioxide Uptake and Incorporation by Phaseolus vulgaris (L.)," Science, Vol. 206, No. 4416, 1979, pp. 333335. doi:10.1126/science.206.4416.333

[14] T. Yoneyama and H. Sasakawa, "Transformation of Atmospheric Nitrogen Dioxide Absorbed in Spinach Leaves," Plant and Cell Physiology, Vol. 20, 1979, pp. 263-266.

[15] A. R. Wellburn, "Why Are Atmospheric Oxides of Nitrogen Usually Phytotoxic and Not Alternative Fertilizers?" New Phytologist, Vol. 115, No. 3, 1990, pp. 395429. doi:10.1111/i.1469-8137.1990.tb00467.x

[16] H. Morikawa, A. Higaki, M. Nohno, M. Takahashi, M. Kamada, M. Nakata, G. Toyohara, Y. Okamura, K. Matsui, S. Kitani, K. Fujita, K. Irifune and N. Goshima, "More than a 600-Fold Variation in Nitrogen Dioxide Assimilation among 217 Plant Taxa," Plant, Cell and Environment, Vol. 21, 1998, pp. 180-190. doi:10.1046/j.1365-3040.1998.00255.x

[17] M. Takahashi, Y. Sasaki, S. Ida and H. Morikawa, "Enrichment of Nitrite Reductase Gene Improves the Ability of Arabidopsis thaliana Plants to Assimilate Nitrogen Dioxide," Plant Physiology, Vol. 126, No. 2, 2001, pp. 731741. doi:10.1104/pp.126.2.731

[18] H. Morikawa, M. Takahashi, A. Sakamoto, T. Matsubara, G. Arimura, Y. Kawamura, K. Fukunaga, K. Fujita, N. Sakurai, T. Hirata, H. Ide, N. Nonoyama and H. Suzuki,
"Formation of Unidentified Nitrogen in Plants: An Implication for a Novel Nitrogen Metabolism," Planta, Vol. 219 , No. 1, 2004, pp. 14-22. doi:10.1007/s00425-003-1200-7

[19] M. Takahashi, A. Higaki, M. Nohno, M. Kamada, Y. Okamura, K. Matsui, S. Kitani and H. Morikawa, "Differential Assimilation of Nitrogen Dioxide by 70 Taxa of Roadside Trees at an Urban Pollution Level," Chemosphere, Vol. 61, No. 5, 2005, pp. 633-639. doi:10.1016/j.chemosphere.2005.03.033

[20] X.-Y. Yang, W.-P. Chen, A. K. Rendah, A. D. Hegeman, W. M. Gray and J. D. Cohen, "Measuring the Turnover Rates of Arabidopsis Proteins Using Deuterium Oxide: An Auxin Signaling Case Study," The Plant Journal, Vol. 63, No. 4, 2010, pp. 680-695. doi:10.1111/j.1365-313X.2010.04266.x

[21] S. E. H. Adam, J. Shigeto, A. Sakamoto, M. Takahashi and H. Morikawa, "Atmospheric Nitrogen Dioxide at Ambient Levels Stimulates Growth and Development of Horticultural Plants," Botany, Vol. 86, No. 2, 2008, pp. 213-217. doi:10.1139/B07-129

[22] Y. Kawamura, K. Fukunaga, A. Umehara, M. Takahashi and H. Morikawa, "Selection of Rhododendron mucronatum Plants that Have a High Capacity for Nitrogen Dioxide Uptake," Acta Biotechnologica, Vol. 22, No. 1-2, 2002, pp. 113-120. doi:10.1002/1521-3846(200205)22:1/2<113::AID-ABIO1 $13>3.0 . \mathrm{CO} ; 2-\mathrm{B}$

[23] J. Shigeto, S. Yoshihara, S. E. H. Adam, K. Sueyoshi, A. Sakamoto, H. Morikawa and M. Takahashi, "Genetic Engineering of Nitrite Reductase Gene Improves Uptake and Assimilation of Nitrogen Dioxide by Rhaphiolepis umbellata (Thunb.) Makino," Plant Biotechnology, Vol. 23, 2006, pp. 111-116. doi:10.5511/plantbiotechnology.23.111

[24] M. Takahashi, S. Kohama, J. Shigeto, Y. Hase, A. Tanaka and H. Morikawa, "Mutants of Ficus pumila Produced by Ion Beam Irradiation with an Improved Ability to Uptake and Assimilate Atmospheric Nitrogen Dioxide," International Journal of Phytoremediation, Vol. 14, No. 3, 2012, pp. 275-281. doi:10.1080/15226514.2011.604694

[25] A. Tanaka, N. Shikazono, Y. Yokota, H. Watanabe and S. Tana, "Effects of Heavy Ions on the Generation and Survival of Arabidopsis thaliana," International Journal of Radiation Biology, Vol. 72, No. 1, 1997, pp. 121-127. doi: $10.1080 / 095530097143608$

[26] H. Kacser and J. W. Porteous, "Control of Metabolism: What Do We Have to Measure?" Trends in Biochemical Sciences, Vol. 12, No. 1, 1987, pp. 5-14. doi:10.1016/0968-0004(87)90005-3

[27] M. Stitt and U. Sonnewald, "Regulation of Metabolism in Transgenic Plants," Annual Review of Plant Physiology and Plant Molecular Biology, Vol. 46, 1995, pp. 341-368. doi:10.1146/annurev.pp.46.060195.002013

[28] M. Takahashi, M. Nakagawa, A. Sakamoto, C. Ohsumi, T. Matsubara and H. Morikawa, "Atmospheric Nitrogen Dioxide Gas Is a Plant Vitalization Signal to Increase Plant Size and the Contents of Cell Constituents," New Phytologist, Vol. 168, No. 1, 2005, pp. 149-154. 


$$
\text { doi:10.1111/j.1469-8137.2005.01493.x }
$$

[29] T. M. Capron and T. M. Mansfield, "Inhibition of Growth in Tomato by Air Polluted with Nitrogen Oxides," Journal of Experimental Botany, Vol. 28, No. 1, 1977, pp. 112116. doi:10.1093/jxb/28.1.112

[30] H. Saxe, "Relative Sensitivity of Greenhouse Pot Plants to Long-Term Exposures of $\mathrm{NO}$ - and $\mathrm{NO}_{2}$-Containing Air," Environmental Pollution, Vol. 85, No. 3, 1994, pp. 283-290. doi:10.1016/0269-7491(94)90049-3

[31] R. Sandhu and G. Gupta, "Effects of Nitrogen Dioxide on Growth and Yield of Black Turtle Bean (Phaseolus vulgaris L.) cv. 'Domino,"” Environmental Pollution, Vol. 59, No. 4, 1989, pp. 337-344. doi:10.1016/0269-7491(89)90160-7

[32] Q. Xu, B. Zhou, C. Ma, X. Xu, J. Xu, Y. Jiang, C. Liu, G. Li, S. J. Herbert and L. Hao, "Salicylic Acid-Altering Arabidopsis Mutants Response to $\mathrm{NO}_{2}$ Exposure," Bulletin of Environmental Contamination and Toxicology, Vol. 84, No. 1, 2010, pp. 106-111. doi:10.1007/s00128-009-9913-3
[33] D. M. Vallano and J. P. Sparks, "Quantifying Foliar UpTake of Gaseous Nitrogen Dioxide Using Enriched Foliar $\partial^{15} \mathrm{~N}$ Values," New Phytologist, Vol. 177, No. 4, 2008, pp. 946-955. doi:10.1111/j.1469-8137.2007.02311.x

[34] M. Takahashi, S. E. Adam, D. Konaka and H. Morikawa, "Nitrogen Dioxide at an Ambient Level Improves the Capability of Kenaf (Hibiscus cannabinus) to Decontaminate Cadmium," International Journal of Phytoremediation, Vol. 10, No. 1, 2008, pp. 73-76. doi: $10.1080 / 15226510701827085$

[35] M. Takahashi, A. Sakamoto, H. Ezura and H. Morikawa, "Prolonged Exposure to Atmospheric Nitrogen Dioxide Increases Fruit Yield of Tomato Plants," Plant Biotechnology, Vol. 28, No. 5, 2011, pp. 485-487. doi:10.5511/plantbiotechnology.11.0819a

[36] F. H. F. G. Spierings, "Influence of Fumigations with $\mathrm{NO}_{2}$ on Growth and Yield of Tomato Plants," Netherlands Journal of Plant Pathology, Vol. 77, No. 6, 1971, pp. 194-200. doi:10.1007/BF01977278 